\title{
Evaluation of Antidepressant Potential of Hydrastis canadensis in Mice
}

\author{
Sadia Batool*, Haneen Saeed, Sarah Yehya, Rasha Ali, Afia Mofreh, Hanaa Saeed \\ Department of Pharmacology, College of Pharmacy, King Khalid University, Abha, Kingdom of Saudi Arabia
}

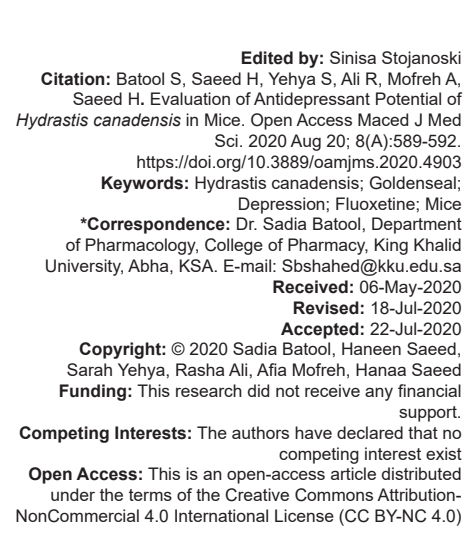

\section{Introduction}

Depression is one of the most common chronic psychological disorders presenting around the world [1]. Depression presents with many interpersonal and social problems. Some of the signs and symptoms are changes in sleep pattern, negative thoughts, and loss of interest in daily activities [2]. This disorder leads to functional impairment and in chronic cases can cause cardiovascular complications such as myocardial infarction and stroke. The most important complication due to this disease is suicide. The main cause of depression is mainly due to low levels of neurotransmitters in the central nervous system such as dopamine and serotonin [2]. Endocrinological factors along with abnormality of circadian rhythm are some of the other reasons for this disorder [3]. Treatment for depression includes many prescription drugs. The main group of drugs includes TCAs (tricyclic antidepressants), SSRIs (selective serotonin reuptake inhibitors), and NARIs (non-adrenaline reuptake inhibitors). Patient compliance is low as adverse effects are common and are basis of discontinuation of treatment [4]. SSRIs are used more commonly, but are associated with side effects such as drowsiness, diarrhea, insomnia, restlessness, and sexual problems [5]. Tricyclic antidepressants are generally not tolerated well and are associated with many more adverse effects, mostly anticholinergic effects (blurred vision, dry mouth, constipation, and urinary retention) [6]. NARIs and SNRIs have similar effects with addition of sweating and flushing, tachycardia, and hypertension [7]. Along with adverse effects, the newer drugs also carry financial burden. Therefore, there is a need of discovering newer, safer, cost-effective alternative therapies. Golden seal is also called Hydrastis canadensis belongs to the buttercup family. It is a perennial herb with a yellowish color. This herb was approved in the USA Pharmacopoeia and in the national formulary in the $18^{\text {th }}$ and $19^{\text {th }}$ century [8]. Conventionally, it is used for treatment and prevention of flu and cold. It is a rich herb with many phytoconstituents ranging from amino acids to alkaloids, flavonoids, and steroids. The most common constituents found in this herb are alkaloids including hydrastine, canadine, and berberine [9]. An alkaloid, berberine, derived from this plant is used in Chinese folklore tradition for mood elevating 
effects [10], [11]. This herb is useful for treating and preventing flu and cold. It has documented antibacterial, immune enhancing, anti-inflammatory, antioxidant, and anticancer effects [12], [13], [14], [15]. This plant is rich in phytoconstituents; however, its effects at central nervous system have not been evaluated. As the plant is used as an antidepressant in alternative medicine and is rich in various implicated phytoconstituents, it can demonstrate CNS stimulant effects. Therefore, our study is aimed at evaluating the antidepressant effects in mice by assessing the locomotor index using an actimeter.

\section{Materials and Methods}

\section{Drugs and plant materials}

Fluoxetine hydrochloride $10 \mathrm{mg}$ tablets (Prozac (TN), SPIMACO, Al-Qassim Pharmaceuticals Goldenseal (Hydrastis canadensis) root) and GNC Herbs (Starwest Botanicals) were used.

\section{Preparation of ethanolic extract}

Ethanolic extract was prepared by maceration technique. A $50 \mathrm{~g}$ of dried root (Hydrastis canadensis) was crushed to fine powder and placed in $500 \mathrm{ml}$ ethanol [16]. The mixture will be shaken frequently for 3 days [16]. Next, after filtration, the filtrate was dried in rotary evaporator (temperature at $60^{\circ} \mathrm{C}$, rotations at $80 / \mathrm{min}$ ). The dried filtrate was stored in clean sealed test tubes and kept in refrigerator until further use.

\section{Phytochemical analysis}

Extract was evaluated for the presence of flavonoids, phenols, alkaloids, steroids, and tannins by preliminary phytochemical screening [17].

\section{Animals/Grouping}

Swiss albino mice (18-30 g) of either sex were provided by the animal house at King Khalid University, Abha, Saudi Arabia. Animals were kept in free area in cage, maintained on standard light cycle (12 h light/ dark), and supplied with standard food and water. All experiments were carried out after ethical approval from Ethics Committee, King Khalid University. The animals were grouped as follows $(n=5)$ :

$\begin{array}{ll}\text { - } & \text { Group I: Tween-80 (negative control) } \\ \text { - } & \text { Group II: Fluoxetine } 10 \mathrm{mg} / \mathrm{kg} \text { (positive control) } \\ \text { - } & \text { Group III: H. canadensis extract } 150 \mathrm{mg} / \mathrm{kg} \\ & \text { Group IV: H. canadensis extract } 250 \mathrm{mg} / \mathrm{kg}\end{array}$

\section{Antidepressant activity (Locomotor activity)}

The animal locomotor behavior was monitored using actimeter (Panlab Harvard Apparatus). This apparatus has a square arena with a light source provided with photocells. The locomotor activity was recorded with a digital counter. Each animal was placed individually in the apparatus and its basal movement was recorded for 5 min [18]. Next, each animal was treated with respective drug (intraperitoneal injection) and activity score was recorded after 30 $\mathrm{min}$ and $1 \mathrm{~h}$ [18]. The extract dose was $150 \mathrm{mg} /$ $\mathrm{kg}$ and $250 \mathrm{mg} / \mathrm{kg}$ [19], [20]. Extract was dissolved in 1\% Tween-80 for intraperitoneal injection. Mean of activity score for each group was calculated and compared. Increased activity score was taken as index of antidepression [18].

\section{Statistical analysis}

All data were expressed as mean \pm SEM and analyzed using ANOVA. $p<0.05$ was considered statistically significant.

\section{Results}

The phytochemical analysis yielded positive results for alkaloids and saponins. Flavonoids, steroids, and tannins were negative (Table 1). Mean of each group was taken and compared. Locomotion was increased in groups treated with fluoxetine and extract at $150 \mathrm{mg}$ and $250 \mathrm{mg} /$ $\mathrm{kg}$ dose at $30 \mathrm{~min}$ and $60 \mathrm{~min}$ when compared to negative

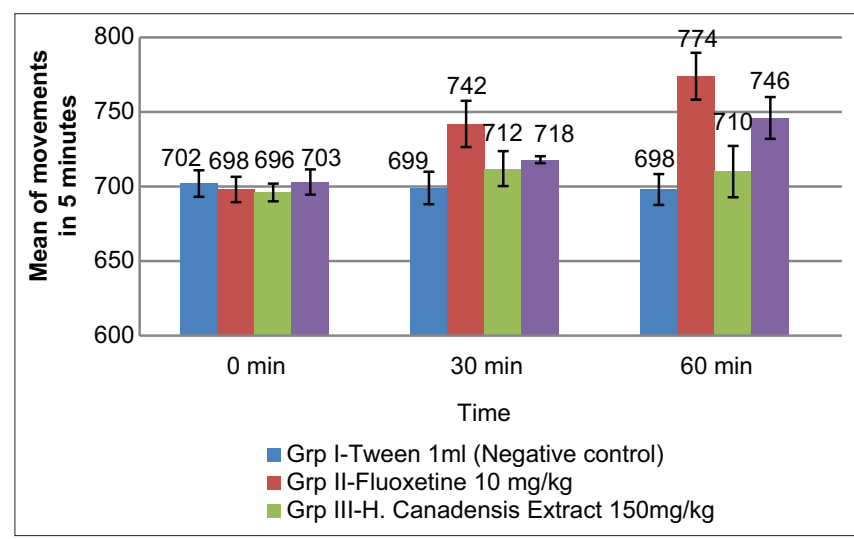

Figure 1: Assessment of locomotor activity

control (Figure 1). This was an index of antidepressant effect. However, the results were statistically significant $(p<0.05$ ) for fluoxetine (at $30 \mathrm{~min}$ and $60 \mathrm{~min}$ ) and extract treated groups at $250 \mathrm{mg} / \mathrm{kg}$ (at $60 \mathrm{~min}$ ). Fluoxetine demonstrated the highest antidepressant effect followed on by extract at $250 \mathrm{mg} / \mathrm{kg}$ dose (Table 2).

Table 1: Phytochemical screening of Hydrastis canadensis extract

\begin{tabular}{llllll}
\hline Compound & Tannins & Alkaloids & Flavonoids & Steroids & Saponins \\
\hline Result & Negative & Positive & Negative & Negative & Positive \\
\hline
\end{tabular}


Table 2: Mean \pm SEM (locomotor activity in $5 \mathrm{~min}$ )

\begin{tabular}{llll}
\hline Group & $\begin{array}{l}0 \text { min } \\
\text { (baseline) }\end{array}$ & $\begin{array}{l}30 \mathrm{~min} \\
\text { (after dose) }\end{array}$ & $\begin{array}{l}60 \mathrm{~min} \\
\text { (after dose) }\end{array}$ \\
\hline $\begin{array}{l}\text { Group I - Tween 1 ml } \\
\text { Negative control }\end{array}$ & $702 \pm 8.9$ & $699 \pm 10.9$ & $698 \pm 10.4$ \\
$\begin{array}{l}\text { Group II - Fluoxetine 10 mg/kg } \\
\text { Group III - H. Canadensis extract }\end{array}$ & $698 \pm 8.5$ & $742 \pm 15.5^{\star}$ & $774 \pm 15.7^{*}$ \\
$\begin{array}{l}150 \mathrm{mg} / \mathrm{kg} \\
\text { Group IV }- \text { H. Canadensis extract }\end{array}$ & $703 \pm 8.5$ & $712 \pm 11.7$ & $710 \pm 17.2$ \\
$\begin{array}{l}250 \mathrm{mg} / \mathrm{kg} \\
{ }^{*} P \text { value is significant (<0.05) when compared to negative control (calculated by one-way ANOVA) }\end{array}$
\end{tabular}

\section{Discussion}

Depression is a debilitating disease with many effects at personal and social levels. Although there are many drugs available for its treatment, they come with the burden of adverse effects and dependence. Traditional plants are used nowadays to counteract this disease. One famous plant is St. Johns Wort, it has extensive application as an antidepressant [21]. New plants are being evaluated for the same. The active constituents in plants, which have proven effects as antidepressants, are flavonoids and alkaloids. In this study, phytochemical analysis of plant was positive for alkaloids and saponins. The extract documented statistically significant antidepressant potential at $250 \mathrm{mg} / \mathrm{kg}$. Alkaloids have documented antidepressant effects. One famous alkaloid, berberine, derived from plants is already in use as a mood stimulant in China [22]. Some of its effects include modulation of serotonergic, noradrenergic, and dopaminergic pathways [22]. Berberine has also shown significant effects on immobility time and climbing behavior in neuropsychopharmacology experiments carried out in rodents [23]. An alkaloid derived from researchers in Brazil from Psychotria myriantha Mull., also exhibited antidepressant-like effect when studied on serotonin system in rat hippocampus [24]. This alkaloid has numerous effects, such as anti-inflammatory, antitumor, hypolipidemic, antioxidant, and antibacterial [10]. Its effects at neurological levels are an emerging topic. This alkaloid has also been reported to have good penetration and dissolvability in brain [25].

The most important effects of these plant alkaloids are due to their effects on monoamine oxidase (MAO A and B). These enzymes are critical for the metabolism of various neurotransmitters in the brain such as norepinephrine, serotonin, and dopamine [26], [27]. Inhibition on MAOs could increase monoamine neurotransmitters in brain and reduce depressive symptoms [28].

According to monoamine hypothesis, the main pathology in depression is dysregulation of neurotransmitters, mainly serotonin, dopamine, and norepinephrine [29]. Alkaloids have shown to regulate these biogenic neurotransmitters in animal studies. These neurotransmitters are released from neurons during electrical synaptic transmission in the central nervous system.

Monoamine oxidase inhibitors are group of drugs that are already available in the market for treating depression. These drugs, however, come with adverse effects, drug interactions, and increased noncompliance. Some of the side effects are sedation, euphoria, and postural hypotension [30]. Animal studies have proven that plant-based alkaloids have antidepressant potential. These are vastly available in nature and could be a more economical, safer, and long-term therapy for depression.

\section{Conclusion}

This study has indicated antidepressant potential of the ethanolic extract of Hydrastis canadensis root. This could provide an alternative, safer, and costeffective therapy for the treatment of depressive illness.

\section{Limitation}

This is a preliminary study. Larger scale studies with increased number of animals and different test models will be required for validation of results. The mechanism at cellular level could not be evaluated due to limitation in facility resources.

\section{Acknowledgment}

The authors are grateful to the Faculty of Pharmacology Department, King Khalid University, for providing the facilities for this research.

\section{References}

1. Wittchen HU, Jacobi F, Rehm J, Gustavsson A, Svensson M, Jönsson $\mathrm{B}$, et al. The size and burden of mental disorders and other disorders of the brain in Europe 2010. Eur Neuropsychopharmacol. 2011;21(9):655-79.

PMid:21896369

2. Azzopardi LM. Mood disorders. In: Lecture Notes in Pharmacy Practice. London: Pharmaceutical Press; 2010. p. 157-8.

3. Fekadu N, Shibeshi W, Engidawork E. Major depressive disorder: Pathophysiology and clinical management. J Depress Anxiety. 2016;6:255. https://doi.org/10.4172/2167-1044.1000255

4. Fava M. Prospective studies of adverse events related to antidepressant discontinuation. J Clin Psychiatry. 2006;67(4):14-21. 


\section{PMid:16683858}

5. Ferguson JM. SSRI antidepressant medications: Adverse effects and tolerability. Prim Care Companion J Clin Psychiatry. 2001;3(1):22-7. https://doi.org/10.4088/pcc.v03n0105 PMid:15014625

6. Furukawa TA, McGuire H, Barbui C. Meta-analysis of effects and side effects of low dosage tricyclic antidepressants in depression: Systematic review. BMJ. 2002;325(7371):991. https://doi.org/10.1136/bmj.325.7371.991

PMid:12411354

7. Agius M, Hannah B. Antidepressants in use in clinical practice. Psychiatr Danubina. 2017;29(3):667-71.

8. Hobbs C. Golden seal in early American medical botany. Pharm Hist. 1990;32(2):79-82.

PMid:11622733

9. Asmi S, Lakshmi T. Therapeutic aspects of goldenseal. Int Res J Pharm. 2013;4(9):41-3.

10. Kulkarni SK, Dhir A. Berberine: A plant alkaloid with therapeutic potential for central nervous system disorders. Phytother Res. 2010;24(3):317-24. https://doi.org/10.1002/ptr.2968 PMid:19998323

11. Kumar A, Ekavali E, Chopra K, Mukherjee M, Pottabathini R, Dhull DK. Current knowledge and pharmacological profile of berberine: An update. Eur J Pharmacol. 2015;761:288-97. https://doi.org/10.1016/j.ejphar.2015.05.068 PMid:26092760

12. Scazzocchio F, Cometa MF, Tomassini L, Palmery M. Antibacterial activity of Hydrastis canadensis extract and its major isolated alkaloids. Planta Med. 2001;67(6):561-4. PMid:11509983

13. Rehman J, Dillow JM, Carter SM, Chou J, Le B, Maisel AS. Increased production of antigen-specific immunoglobulins $\mathrm{G}$ and $\mathrm{M}$ following in vivo treatment with the medicinal plants Echinacea angustifolia and Hydrastis canadensis. Immunol Lett. 1999;68(2-3):391-5. https://doi.org/10.1016/ s0165-2478(99)00085-1

PMid: 10424448

14. Li Z, Geng YN, Jiang JD, Kong WJ. Antioxidant and antiinflammatory activities of berberine in the treatment of diabetes mellitus. Evid Based Complement Alternat Med. 2014;2014:289264. PMid:24669227

15. Saha SK, Sikdar S, Mukherjee A, Bhadra K, Boujedaini N, Khuda-Bukhsh AR. Ethanolic extract of the goldenseal, Hydrastis canadensis, has demonstrable chemopreventive effects on HeLa cells in vitro: Drug-DNA interaction with calf thymus DNA as target. Environ Toxicol Pharm. 2013;36(1):20214. https://doi.org/10.1016/j.etap.2013.03.023 PMid:23628949

16. Hong DD, Hien HM, Lan HT. Studies on the analgesic and anti-inflammatory activities of Sargassum swartzii Agardh (phaeophyta) and Ulva reticulata Forsskal (Chlorophyta) in experiment animal models. Afr J Biotechnol. 2011;10(12):2308-14.

17. Trease G, Evans SM. Pharmacognosy. $15^{\text {th }}$ ed. London: Bailer Tindal; 2002. p. 23-67.
18. Deepika B, Sweta K, Yadav J, et al. CNS stimulant activity of aqueous extract of roots of Boerhavia diffusa in mice. Indian $J$ Pharmacol. 2013;45(3):264-9.

19. Upton R. Goldenseal root Hydrastis canadensis: Standards of Analysis, Quality Control, and Therapeutics. California: American Herbal Pharmacopoeia; 2001.

20. Roy S, Jyoti S, Rahman A. Anti-carcinogenic potentials of a plant extract (Hydrastis canadensis): Evidence from in vivo studies in mice (Mus musculus). Asian Pac J Can Prev. 2010;11(2):545-51. PMid:20843149

21. Bukhari IA, Dar A. Behavioral profile of Hypericum perforatum (St. John's Wort) extract. A comparison with standard antidepressants in animal models of depression. Eur Rev Med Pharmacol Sci. 2013;17(8):1082-9. PMid:23661522

22. Lee B, Sur B, Yeom M, Shim I, Lee H, Hahm DH. Effect of berberine on depression-and anxiety-like behaviors and activation of the noradrenergic system induced by development of morphine dependence in Rats. Korean J Physiol Pharmacol. 2012;16:379-86. https://doi.org/10.4196/kjpp.2012.16.6.379 PMid:23269899

23. Wang K, Feng X, Chai L, Cao S, Qiu F. The metabolism of berberine and its contribution to the pharmacological effects. Drug Metab Rev. 2017;49:1-19. PMid:28290706

24. Farias FM, Passos CS, Arbo MD, Barros DM, Gottfried C Steffen VM, et al. Strictosidinic acid, isolated from Psychotria myriantha Mull. Arg. (Rubiaceae), decreases serotonin levels in rat hippocampus. Fitoterapia. 2012;83(6):1138-43. https://doi. org/10.1016/j.fitote.2012.04.013 PMid:22546150

25. Wang $\mathrm{X}$, Wang $\mathrm{R}$, Xing $\mathrm{D}$, Su H, Ma C, Ding $\mathrm{Y}$, et al. Kinetic difference of berberine between hippocampus and plasma in rat after intravenous administration of coptidis rhizoma extract. Life Sci. 2005;77(24):3058-67. https://doi.org/10.1016/j. Ifs.2005.02.033 PMid: 15996686

26. Knoll J. History of deprenyl-the first selective inhibitor of monoamine oxidase Type B. Vopr Med Khim. 1997;43(6):482-93 PMid:9503565

27. Wouters J. Structural aspects of monoamine oxidase and its reversible inhibition. Curr Med Chem. 1998;5(2):137-62. PMid:9481038

28. Guangting H, Leilei W, Liu M, Yuanming Z. Component analysis and micro fiber arrangement of Apocynum venetum fibers: The MS and AFM study. Carbohydr Polym. 2008;72(4):652-6. https://doi.org/10.1016/j.carbpol.2007.10.002

29. Jacobsen JP, Medvedev IO, Caron MG. The 5-HT deficiency theory of depression: Perspectives from a naturalistic 5-HT deficiency model, the tryptophan hydroxylase knock in mouse. Philos Trans R Soc Lond B Biol Sci. 2012;367(1601):2444-59. https://doi.org/10.1098/rstb.2012.0109 PMid:22826344

30. Hamilton MS, Opler LA. Akathisia, suicidality and fluoxetine. $J$ Clin Psychiatry 1992;53(11):401-6.

PMid:1364815 